\title{
Different Approaches and Methods of Teaching English
}

\author{
ShakhnozaJalolova ${ }^{1}$, DilshodakhonNazarova ${ }^{2}$, SayyoraDavidova $^{3}$, \\ ShirinaTashpulatova ${ }^{4}$, \\ ${ }^{1}$ Associate Professor, PhD in Philology, National University of Uzbekistan named after MirzoUlugbek, \\ ${ }^{2}$ Senior teacher, Interfaculty department of the English language, National University of Uzbekistan named \\ after MirzoUlugbek. \\ ${ }^{3}$ EL instructor, National University of Uzbekistan named after MirzoUlugbek \\ ${ }^{4}$ Lecturer, Interfaculty department of the English language, National University of Uzbekistan named after \\ MirzoUlugbek,
}

Email: ${ }^{1}$ shahnoza.jalolova@mail.ru, ${ }^{2}$ dilshoda-77@mail.ru, ${ }^{3}$ sayyorajalolova748@ gmail.com,

${ }^{4}$ shirin_8886@mail.ru.

Abstract: In this article, you will find a description of the different approaches to teaching English to students. The topic will be useful for young teachers and those who want to start learning the language on their own. It is important that the consumer understands how his or her linguistic needs are met. Also, after the independence of our country, the interest in teaching foreign languages has increased, and many opportunities for young people will be created, and other issues will be discussed.

Keywords:Education system, effective factor, foreign languages, sectors of the economy, foreign partners.

Article Received: 16th October, 2020; Article Revised: 30th December, 2020; Article Accepted: 08th January, 2021

\section{Introduction}

The economic power of each country, the increase in the level of socio-spiritual life is determined by the competitiveness of the education system, the development of science.

During the years of independence, the reforms being carried out in the education system of our country are an effective factor in the development of the younger generation, both spiritually and physically, in short, on the basis of the idea of a perfect man.

Radical improvement of education on the basis of the Decree of the President of the Republic of Uzbekistan dated February 7, 2017 "On the Strategy for further development of the Republic of Uzbekistan", improving the quality of education, intellectual potential, the formation of a physically fit generation, in-depth training in specific sciences and training of qualified personnel for various sectors of the economy were identified as priorities.

On December 10, 2012, the Decree of the First President "On measures to further improve the system of learning foreign languages" was signed [16]. Thus, day by day, the education system is facing new challenges. Today's era requires any qualified staff to have a thorough knowledge of a foreign language. Starting from the 2013-2014 academic year, foreign languages have been taught in the first grade of schools. That's all the foreign language that teaches first graders before the start of this school year teachers to complete a special training course achieved.

It should be noted that the Republic of Uzbekistan First President Islam Karimov in his speech entitled "Harmoniously developed generation the basis of development of Uzbekistan" at the IX session of the first convocation of the meeting august 1997, which adopted the National Training Program, 
he made the following programmatic comments on foreign language learning: "Currently, great importance is attached to the study and teaching of foreign languages in our country. This, of course, is not in vain. The world today there is no need to overestimate the importance of perfect knowledge of foreign languages for our country, which is striving to take its rightful place in society, for our people, who are building their great future in cooperation with our foreign partners.

However, we must emphasize that learning foreign languages should not be at the expense of forgetting the mother tongue.

\section{The main findings and results}

Mother in our history of learning western languages in our history yesterday not our language, mainly Russian came as a mediator. Due to this, so far, for example, English-Uzbek and UzbekEnglish dictionaries are almost nonexistent.

We need to quickly change such weak and inappropriate situations, to fully open the opportunities for the Uzbek child to enter the wonderful world of foreign languages.

We need to accelerate the development of an accelerated methodology of learning foreign languages on a national basis in our country".

15 years later, the President of the Republic of Uzbekistan it is the adoption of the Resolution "On measures to further improve the system of learning foreign languages" that clearly shows the gradual and consistent nature of the reform of the education system.

Resolution of the First President of the Republic of Uzbekistan dated December 10, 2012 PQ-1875 "On measures to further improve the system of learning foreign languages" and May 23, 2013 "On measures to further improve the system of learning foreign languages" The implementation of the Resolution
PQ-1971 "On measures to improve" requires a great responsibility from every professor. Teaching foreign languages to the younger generation through the introduction of advanced teaching methods using modern pedagogical and information and communication technologies radically, improve the system of training specialists who are fluent in the language and on this basis, their world civilization, conditions and opportunities are being created for their achievements and extensive use of world information resources, development of 29 international cooperation and dialogue.

Currently, there are 9698 educational schools in the country all of them have foreign languages, namely: English in 8643 schools, German in 1589 schools, French in 1076 schools and different in 27 schools (Spanish, Indian, Arabic, Korean, Chinese, etc.) languages are being studied.

More than three and a half million students have started learning foreign languages based on world educational standards. Schools in remote districts and villages of the country are also equipped with modern science classrooms, provided with all the necessary teaching equipment, visual aids and excellent teaching materials. From this example alone, it is difficult to imagine that a very large amount of money is allocated from the state budget for this purpose not.

Also, general secondary schools 5, 6, 8, 9 methodological manuals on foreign languages have been redesigned and published for teachers of foreign languages in accordance with the requirements of the new State Education Standard. In particular, 22,440 copies of manuals and as many multimedia DVDs were distributed and distributed, which further expanded the opportunities for students to learn foreign languages.

According to the program approved by the Cabinet of Ministers of May 27, 2013, 143, in 2013-2016, 17,222 sets of 
foreign language classrooms for grades 1-4 of secondary schools, and 8,735 sets of computer sets for grades 5-9 with equipment is specified. To date, 17,222 foreign language classrooms have been set up to teach foreign languages in the primary grades, all of which have been equipped with DVD players, teaching aids, dictionaries and literature. According to the program, in 2013, 2457 laptops in this class, projectors and other technical equipment, in 2014, 4193 foreign languages for 30 primary classes and 1500 senior classes equipment for cabinets was delivered.

The current stage of development of society is the science and development of education requires integration with the output. The conformity of the content of education to the requirements of science and industry ensures the sustainable development of the socio-economic and spiritual-cultural life of society. The main task of the state education standards is to ensure the socio-economic reforms of the education system in the country, the organization based on science and modern information and communication technologies is based on the same need . Indeed, the success of the reforms, the country's worthy place among the developed, modern countries of the world, is inextricably linked with the development of science and education, in this regard, our ability to compete globally.

That's why, the state policy on education in our country is based on the innovations of science, its new achievements, particular attention is paid to the implementation of research results in the educational process, ensuring the integration of the educational process with real life and, on this basis, the humanization of education.

A number of government decisions have been made in this direction. In particular, the First President of the Republic I. Karimov on December 10, 2012, "Further development of the system of learning foreign languages, resolution PQ-1875 "On measures to improve" has taken the first steps to pay more attention to foreign language teaching in our country.

This decision is a modern pedagogical and information-communication through the introduction of advanced teaching methods using foreign technologies, radically improving the system of teaching the younger generation in foreign languages, training specialists fluent in these languages, and on this basis, their achievements in 31 world civilizations and extensive use of world information resources, international cooperation and communication and it aimed to create conditions and opportunities for their development .

On May 8, 2013, the President of the Republic of Uzbekistan "On measures to further improve the system of learning foreign languages" dated December 10, 2012 PQ-1875 the resolution of the Cabinet of Ministers of the Republic of Uzbekistan "On approval of the state standard of education in foreign languages of the system of continuing education" has been implemented [22; 251].

Today, a total of 27,342 foreign language teachers work in secondary schools. Of these, 21,611 (77.3 per cent) were English language, 3324 (13.3 per cent) are German, 2302 (8.9 per cent) are French and 105 (0.4 per cent) are other foreign language teachers. However, we cannot say that all our schools are fully staffed with mature professional teachers in the field of knowledge, experience and skills.

On this basis, the quality of teachers working in educational institutions was also a priority. That is why on October 10, 2013 the order of the Director of the State Testing Center under the Cabinet of Ministers of the Republic of Uzbekistan "On approval of the Regulations on the procedure for conducting tests to determine the monthly increase in the 
basic salary of foreign language teachers" was implemented.

This Regulation provides for additional payments to educational institutions, approved by the Decree of the President of the Republic of Uzbekistan dated December 10, 2012 PQ-1875 "On measures to further improve the system of learning foreign languages" and the Cabinet of Ministers dated September 29, 1994, 490 list of positions of pedagogical staff, types of these payments and professional and special disciplines of foreign languages, foreign philology, foreign language and translation of educational institutions the procedure for conducting tests to determine the monthly increase in the basic salaries of professors and teachers reflected the designation .

It should be noted that the creation of a unique system of incentives for foreign language teachers also inspires them to work selflessly, to take a creative approach to their duties. Resolution of the Cabinet of Ministers 109 of April 19, 2013 to establish an additional bonus of $30 \%$ for foreign language teachers in rural schools and $15 \%$ for teachers in urban schools, the order was approved. Resolution of the President of the Republic of Uzbekistan PQ-1875 of December 10, 2012 "On measures to further improve the system of learning foreign languages" and the Cabinet of Ministers of March 25, 2015 "On measures to further improve the system of learning foreign languages" and the Ministry of Public Education of the Republic of Uzbekistan on the implementation of the Resolution 67 "On additional measures to improve professional skills" among teachers of 33 secondary schools of the Ministry of Public Education of the Republic of Uzbekistan Foreign Language Teacher Competition".

This competition is held in three stages and operates in the system delivered to all foreign language teachers through methodical days (every Friday of the week) and mass media on the basis of the newly introduced mechanism, by creating a healthy competitive environment among foreign language teachers by ensuring the voluntary participation of all foreign language teachers in the competition, as well as identifying and encouraging their skills among them.

Further development of foreign language learning, international the level of training of highly qualified foreign language teachers for secondary schools, vocational colleges and academic lyceums, higher education institutions in accordance with the standards and quality improvement. In order to ensure the implementation of measures $\mathrm{I}$. Karimov issued another resolution on May 23, 2013, entitled "Improving the activities of the Uzbek State University of World Languages Resolution PQ-1971 "On Measures" was adopted.

Among the resolutions and decrees on further reforming the education system, President of the Republic of Uzbekistan Sh. Mirziyoyev's 2017 34, we can cite the decision of April 20 "On measures to further develop the system of higher education".

Resolution of the President of the Republic of Uzbekistan "On measures to further develop the system of higher education" radical improvement, in accordance with the priorities of socioeconomic development of our country, adopted in order to radically reconsider the meaning and content of training, to create the necessary conditions for the training of highly qualified specialists at the level of international standards.

Complete the effective solution of the tasks set out in the resolution to improve the quality of higher education in order to ensure and radical improvement, logistics of higher education institutions strengthening and modernizing the base, in order to equip them with modern educational laboratories, information and 
communication technologies, a comprehensive development program of the higher education system for 20172021 was approved.In this program, basically with every higher education institution in the country cooperation with leading scientific and educational institutions of the United States, Great Britain, France, Italy, the Netherlands, Russia, Japan, South Korea, China and other countries is very important. On this basis, every year more than 350 highly qualified foreign teachers and scientists study in our country, it is planned to involve them in the educational process.

Resolution of the President of the Republic of Uzbekistan "On measures to further develop the system of higher education" development of the system of continuing education, providing the steadily developing economy of the country with highly qualified personnel, is another important practical step towards expanding the participation of the higher education system in addressing the issues of strategically integrated development of all regions and sectors .

Now a huge database of experiences that a teacher can use throughout his / her career has been formed and it is getting richer day by day. But, nevertheless, teachers and future professions it is with some difficulty that the owners assimilate these experiences.

This can be explained by the fact that the skills and abilities of teachers to analyze and select these experiences are underdeveloped. We can see that they do not pay enough attention to reviewing the experiences they have accumulated during their practice and the activities of their colleagues.

One thing to keep in mind is that advanced pedagogical practices are of a somewhat limited nature. In addition, pedagogical experiments incorporate new elements that enrich the practice and theory of education.
It is well known that in times of change, the education system requires rapid development based on social processes. Through education, a new generation is formed in society that is able to perform future tasks.

In this regard, special attention is paid to strengthening the material and technical base of secondary schools and preschools, creating the necessary conditions and opportunities for the younger generation to receive a comprehensive education.

At the initiative of the President, 9th grade students, parents and at their discretion, are consciously compulsory in vocational colleges, academic lyceums or schools where they are educated the determination that they could continue their education has created all-round conveniences for the youth.

As a result of such reforms in our country, huge economic growth is being achieved the demand for staff and mature professionals are growing.

Satisfaction of such a demand, in turn, is among young people increase interest in reading and lessons and teachers' attention to comprehensive educational upbringing there is a need to implement strengthening through modern social innovations.

Experts of the Independent Institute for Monitoring the Formation of Civil Society are exactly such requirements today

Assess the development of education and science in most foreign countries and, given that it is very important for the education system 88 reviewed some best practices aimed at improving the quality of education through monitoring.

It is known that secondary and secondary special education is a continuing educationto organize the second stage of the system and bring it to a new stage of development, further reform, as well as higher education. Significant work is also being done on qualified delivery. In particular, on October 16, 2000, the 
Cabinet of Ministers of the Republic of Uzbekistan issued a decree "On state education of secondary special, vocational education. Resolution 400 "On approval of standards" was put into practice. This decision will further improve the secondary education system, curricula of secondary special and vocational education and set the standards for their plans. This standard secondary special, The Law of the Republic of Uzbekistan "On Education", the Law of the Republic of Uzbekistan "On the National Training Program" is the basis of a set of standards of vocational education, Resolution of the Cabinet of Ministers of the Republic of Uzbekistan "On the development and implementation of state educational standards for the system of continuing education" dated January 5, 19985 and based on the Resolution of the Cabinet of Ministers of the Republic of Uzbekistan dated May 13, 1998204 "On measures to organize secondary special, vocational education in the Republic of Uzbekistan" obtained.

The implementation of this decision has a number of objectives, which include: "The high quality of the CSTO and the deep economic and social reforms being carried out in the country, the developed democracy ensuring the training of competitive personnel that meet the requirements of state building; from the prospects of social and economic development of the country, the needs of society, science, technology and regulation of the content of training 89 based on modern advances in technology; Democratization of the CSTO, humanization and socialization, legal and increase the level of economic knowledge, as well as the effectiveness of the educational process; the provision of quality educational services, training and protection of the interests of the individual, society and the state in the field of training; establishment of criteria and procedures for assessing the quality of training and educational activities; CSTO process and staffing ensuring consistency and continuity of training; Ensuring competitiveness in the market of labor and educational services .

To the CSTO and its final results, the order of periodic assessment of students' knowledge and professional skills, as well as the creation of a regulatory framework that sets out the relevant requirements for quality control of educational activities; introduction of effective forms and methods of spiritual and moral education of students on the basis of the rich intellectual heritage of the people and universal values;

In the process of teaching and learning, pedagogical and informational to provide technology, to control the level of education, establishment of norms and requirements for the qualifications of students and their graduates in educational institutions; Ensuring effective integration of education, science and industry for targeted and quality training.

From the above, it is clear that with a special focus on the system of secondary and secondary special education, its further reform and development is becoming increasingly important.

It should be noted that today the level of knowledge of a foreign language is regulated by a number of laws and regulations the degree to which a language is mastered is determined by these means.

Radical reforms in the education system during the years of independence, the world intellectual, who can meet the requirements of today's time, make a worthy contribution to the future development of our country, aimed not only at the consumer of the property, but also at training a harmoniously developed generation, mature professionals capable of creating and enriching it.

This goal is reflected in the essence of the resolution of the First President "On 
measures to further improve the system of learning foreign languages".

In particular, through the introduction of advanced methods of teaching using modern pedagogical and information and communication technologies, the teaching of foreign languages to the younger generation, the development of specialists who are fluent in these languages, radical improvement of the training system and on this basis, their achievements in world civilization as well as the vastness of world information resources scale use, international cooperation and communication. Creating conditions and opportunities for their development is one of the important tasks before us.

Educational institutions with qualified foreign language teachers special attention is paid to the training of personnel with in-depth knowledge. In this case, too, from the available opportunities certain work has been done, important tasks for the near future have been identified in cooperation with higher education institutions.

The problem of staffing can be completely solved not only by meeting the need in terms of numbers, but also by achieving the teaching of teachers with high potential as teachers, fluent in foreign languages. It is necessary for them to regularly improve their skills, to create conditions and environment for them to work on themselves.

New methods and requirements for teaching foreign languages in the country have been developed in accordance with the recommendations of the PanEuropean Framework for Assessment of Knowledge and Skills of Foreign Language Teachers (CEFR). According to him, textbooks have been created for students of secondary schools and vocational colleges. In accordance with these requirements, classrooms are equipped with stands and new information and communication technologies. The demand for learning a foreign language is growing day by day. Foreign language science is divided into four aspects (reading, reading, listening comprehension and speaking), each of which provides specific concepts and skills. Educational technology is the effective use of modern information technology in the educational process. It also aims to improve the quality and effectiveness of education through the introduction of modern innovative technologies in the educational process. In particular, there are several advantages to using such information and communication technologies in learning a foreign language. The role of modern technology in language learning and teaching is invaluable.

The goals of foreign language teaching are determined by the needs of society, social order, conditions and policies. The goals of foreign language teaching depend on the development and progress of the society. Teaching a foreign language in higher education institutions has its own goals, and all coaches who teach a foreign language must make it clear in advance.

Upon graduation, students are required to be able to receive, comprehend, and express their ideas orally and in writing, both orally and in writing. In higher education institutions that do not specialize in languages, the number of teaching hours is given in the programs of those institutions. In non-philological educational institutions, foreign languages are taught on the basis of special curricula.

Currently, language materials in foreign languages (English, German, French) have been selected for the higher education institution. Properly selected content will help you achieve your goals. Content selection takes into account the purpose of the training and is guided by it. When the content is selected, along with the language materials, speech 
patterns are also selected. They are the basis for teaching speech.

\section{Conclusion}

In order to organize future work more effectively, to avoid the same shortcomings and problems again and again, we need to clearly define the content of the work to be done and make a careful plan,to organize our activities on this basis, to determine the topics of scientific conferences on the problems of foreign language teaching in primary school with the involvement of international experts, local Methodist scholars, the current state of foreign language teaching in secondary schools, established state educational standards, curriculaand textbook improvement,qualification of teachers regular monitoring of the level of education, strengthening the constant monitoring of the analysis of the psychological state of students in learning foreign languages, further strengthening the process of teaching a foreign language activation, these include the organization of financial incentives for foreign language teachers and students, the organization of various competitions, the organization of trips abroad based on the results.

\section{References}

[1] Richards, J. C., \& Rodgers, T. S. (2014). Approaches and methods in language teaching. Cambridgeuniversitypress.

[2] Salakhova, E. Z., \&Shamsitdinova, M. G. (2020). ADVANCED PEDOGOGICAL

TECHNOLOGIES IN EDUCATION IN THE 21-ST CENTURY. Theoretical\&AppliedS cience, (5), 743-746.

[3] Elizabeth, M. E. S. (2010). Methods of teaching English. DiscoveryPublishingHouse.
[4] Shamsitdinova, M. G. (2020). INTERCULTURAL COMMUNICATION AND PROBLEMS OF TEACHING ENGLISH TO THE STUDENTSNONLINGUISTS. Theoretical \&Ap pliedScience, (4), 1024-1026.

[5] Sodirjonov, M. M. (2020). Some Thoughts On The Evolution Of Approaches To The Concept Of Human

Capital. TheAmericanJournalofSoci alScienceandEducationInnovations, 2(08), 144-150.

[6] Heidari, A., Ketabi, S., \&Zonoobi, R. (2014). The role of culture through the eyes of different approaches to and methods of foreign language teaching. JournalofInterculturalCo mmunication, 34(6).

[7] Shamsitdinova, M. THE IMPACT $\mathrm{OF}$ INFORMATION TECHNOLOGIES ON DISTANCE EDUCATION DURING PANDEMIC IN THE REPUBLIC OF UZBEKISTAN. PalArch'sJournalo fArchaeologyofEgypt/Egyptology. ISSN, 8962-8967.

[8] Davlatova, R. H. (2020). USING UZBEK NATIONAL GAMES IN PRE-SCHOOL EDUCATIONAL INSTITUTIONS. Theoretical\&App liedScience, (4), 112-114.

[9] Liu, Q. X., \& Shi, J. F. (2007). An Analysis of Language Teaching Approaches and Methods-Effectiveness and Weakness. OnlineSubmission, 4(1), 69-71.

[10] Haydarovna, D. R. (2020). Social condition deixis and its expression in uzbek language. ACADEMICIA: AnInternationalMultidisciplinaryRe searchJournal, 10(4), 259-265.

[11] Lutfullaeva, D. (2020, December). ASSOCIATIVE MEANING AND VERBAL ASSOCIATIONS 
LANGUAGE PROPERTIES. In Конференции.

[12] Rustamiy, S., Lutfullaeva, D., \&Gulomova, H. (2020). THE IMPORTANCE OF BALAGHA SCIENCE IN AESTHETIC EDUCATION. PalArch'sJournalof ArchaeologyofEgypt/Egyptology, 1 7(6), 8882-8886.

[13] Esonovna, L. D., Anvarovna, N. M., Sayidmahamadovna, S. N., Alimullaevna, N. F., \&Kakhramanovna, S. N. (2020). Pragmatic features of official texts and documents of the uzbek language. ANGLISTICUM. Journal of the Association-Institute for English Language and American Studies, 9(7), 27-34.

[14] Zaripova, M. (2020). THE NEW METHODS OF TEACHING ENGLISH LANGUAGE. Архив Научных Публикаций JSPI, 1-261.

[15] Lutfullayeva, D. E. (2016). The Role Of Associative Experimental Method In The StudyOf Human Linguistic Memory. In Современные проблемы тюркологии: язык-литературакультура (рр. 452-457).

[16] Лутфуллаева, Д. (2017). Ассоциативтилшуносликназария си. Тошкент: Meriyus.

[17] Rossell, C. (2005). Teaching English through English. EducationalLeadership, 62 (4), 32-36.

[18] Sattorova, Z. I. (2020). ANALYSIS OF MAHMUD AL-KASHGARI SONGS IN "DIWAN LUGHAT AL-TURK". In WORLD SCIENCE: PROBLEMS AND INNOVATIONS (pp. 105-109).

[19] Ismoilovna, S. Z. (2020). Ideological interpretation of seasonal and ceremonial songs in "Diwanlughat al-turk""Compendium of the languages of the turks". AsianJournalofMultidimensi
onalResearch (AJMR), 9(6), 165171.

[20] Bahremand, A. (2015). The concept of translation in different teaching approaches and methods. JournalofSocialSciencesa ndHumanitiesResearch, 3(01), 610.

[21] Nomass, B. B. (2013). The impact of using technology in teaching English as a second language. Englishlanguageandliter aturestudies, 3(1), 111.

[22] Doniyorov, A., Kariev, A., Aminov, H., \&Karimov, N. (2021). The Level of Study of the Religious Image of Mavarounnahr in the IXXII

Centuries. JournalofContemporaryI ssuesinBusinessandGovernmentVol ,27(1). 